\title{
ARTICULATING STATUS IN ANCIENT GREECE: STATUS (IN)CONSISTENCY AS A NEW APPROACH
}

\author{
P. A. Davies ${ }^{\star}$ \\ University of Nottingham
}

Current descriptions of social status in the Greek world are strongly influenced by the works of Moses I. Finley and G. E. M. de Ste. Croix, whose models were grounded in the sociologies of Weber and Marx. This article outlines a new paradigm for social status based on a model from the social sciences, commonly described as status (in)consistency. The article demonstrates the descriptive and interpretive usefulness of this approach using two case studies: social status and social mobility in classical Lakedaimonian society; and the lives and status of Pasion of Acharnai and his son Apollodoros.

\section{Introduction}

Current descriptions of social status in the Greek world are strongly influenced by the works of Moses I. Finley and G. E. M. de Ste. Croix, whose models came out of the debates of the I970s and I980s and were grounded in the sociologies of Weber and Marx. This article will outline a new model for social status based on one first adopted among social scientists during the 1950s, and commonly described as status (in)consistency. Status consistency is a theory seldom cited by ancient historians, with Keith Hopkins' use of the theory in explaining elite mobility in the Roman Empire being a rare exception, ${ }^{\mathrm{I}}$ and I will start by discussing the current models of status used in the study of Greek history. The article will then consider the ways in which sociologists of the last seventy years have understood status before demonstrating the descriptive and analytical utility of this new model using two case studies: the first on a societal scale, discussing Lakedaimonian

\footnotetext{
* peter.a.davies@nottingham.ac.uk
}

I would like to thank all those who have read or heard versions of this piece and from whose input it has greatly benefited: the reviewers and editors at CCJ, my friends at the University of Nottingham, Nick Fisher, Edward Harris, Stephen Hodkinson, Robin Osborne, Claire Taylor and, most importantly, David Lewis, without whom this article would never have seen the light of day. Any mistakes that remain are wholly of my own making.

I Hopkins ( 1965$)$. He used the term 'social dissonance' - though I can find no work of sociology which uses this term for the phenomenon of status inconsistency. 
society; the second on an individual scale, discussing the lives of Pasion of Acharnai and his son Apollodoros.

Many readers will expect to find a concise definition of the term 'status' here at the start. I am loath to provide one. The complexity of such a term defies simple definition, and indeed attempting to reduce this multi-faceted term to one sentence risks drawing the user into overly simplistic ways of thinking about it. However, if one were desperate for a working definition to go along with (while maintaining an awareness of the complexity of the term), I would suggest this: the relative respect and deference accorded to an individual in any given situation. Status elements, therefore, are any properties of an individual which can have an impact upon the relative respect and deference accorded to them in any given situation.

For much of the last fifty years, legal status has generally been privileged in descriptions of social structure and is, as a rule, the basic taxonomy used to locate individuals within ancient society. However, this is just one point in a complex web of status elements. For example, the freedman of an early imperial Roman citizen became a Roman citizen. Their legal status had gone from the lowest of the low to quite a respectable level. However, their friends, family, career, ethnicity, and birth, might in no way have changed. Conversely, a slave sold to the imperial family who made a successful career in the imperial household might experience vast changes in their friends, family, social influence etc., yet might have made no change to their legal status.

There was a great deal of debate over the term status in the I970s and Ig8os. The two fullest and most compelling articulations of status which came of this were those of Finley and de Ste. Croix. These scholars drew largely (and explicitly) from the work of two prominent early sociologists: Weber and Marx. Finley, strongly influenced by the work of Weber, criticised contemporary use of the term 'class' as an articulation of status divisions in the ancient world. ${ }^{2} \mathrm{He}$ instead developed a spectrum of statuses based on what he saw as different elements of social status (including education, wealth and legal status). ${ }^{3}$ De Ste. Croix, influenced by Marxist thinking, aimed to defend Marxist methodologies and maintained class as a useful heuristic tool. He criticised what he described as Finley's 'unfortunate metaphor' of status as a spectrum. ${ }^{4}$ Partially preceding the present work, de Ste. Croix pointed to the implicit contradiction in Finley's work in his referring to the 'criss-crossing categories' in which Roman elites moved, ${ }^{5}$ stating that such a taxonomy was antithetical to a uni-dimensional spectrum. ${ }^{6}$

Deborah Kamen, in her recent work Status in Classical Athens, has given the most thorough and empirically sound exploration of Greek status published since the works of Finley and de Ste. Croix. Her work provides a prime example of the way legal status is privileged in

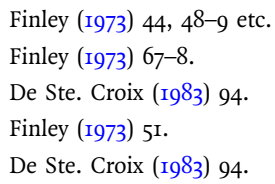


discussions of status. In fact, she comes very close to entirely conflating legal status with a broader description of status and certainly collapses all other elements of status into one overarching category:

Indeed, to the extent that there is any consensus amongst scholars, it is that a category encompassing both social standing and legal rights is a useful one. The question then becomes what to call this category ... In this book, then, I take 'status' to refer to both legal rights and social standing, in keeping with the double way in which modern sociologists use the term. Wherever I want to emphasize one aspect of status, I will specify 'legal status' or 'social status', but I see both as subsets of a larger overarching category, 'status'. '

Kamen is certainly right that her view is generally accepted by the academic community, at least those explicitly writing about status in Greece. Indeed, even in an article which expressly attempts to move 'beyond a legalistic approach' Vlassopoulos uses the terms 'status' and 'legal status' interchangeably. ${ }^{8}$

As Kamen correctly points out, the approach to status among contemporary scholars of ancient history stems largely from the work of Finley and de Ste. Croix. ${ }^{9}$ Kamen is able to identify numerous later studies that work with the formulations of these two scholars to construct definitions of status which fit individuals into social groups based on juridically or economically defined boundaries. ${ }^{\text {Io }}$ As superbly referenced as all of these works are with regard to the developments in the field of ancient history and as well read as they are in the seminal authors of European sociology, none engage with the significant developments in that field which post-date Weber's death in I920. Indeed, Kamen's work ultimately follows a Weberian line. It lays out status along a uni-dimensional spectrum, demarcated primarily by legal status and secondarily by 'privilege'. This latter term is not defined in the work but is used as a tool for dividing some of the legal status groups into what Weber might describe as holders of greater and lesser social prestige. Dividing these legal statuses in this way has already been criticised by Jeremy Trevett, ${ }^{\mathrm{II}}$ who points out that such divisions among slaves, for example, appear to be based upon privileges subject to the essentially arbitrary will of their masters, while those defined for freedmen rest on ambiguous empirical groundings. Yet even Trevett agrees that 'Kamen's central contention, that there were a number of different statuses at Athens arrayed along a spectrum, is persuasively argued, and in one sense obviously correct'.

The scholarly consensus, based on a uni-dimensional spectrum of legal status, makes two major errors. Firstly, it privileges the social definitions of one specific group: legal

\footnotetext{
7 Kamen (2013) 3.

8 Vlassopoulos (2009).

9 See esp. Finley (1973); (I98I) I33-49 et passim; (1983) 70-77; de Ste. Croix (1983) 8I-97 et passim.

Io Hansen (1991); Ober (1989) and (I99I); Todd (1994); Hunter (2000).

II Trevett (20I4).
} 
status may have largely been how the elite male citizens of a polis thought about the divisions of society, but we do not know it was how other social groups divided society in their minds. Might freedmen, for example, have privileged business acumen and economic success over legal status when they were making alliances and striking up friendships, in the fashion we are expected to find satirically amusing in Petronius, or as indicated by Pasion when he made Phormion heir to the running of his bank, rather than

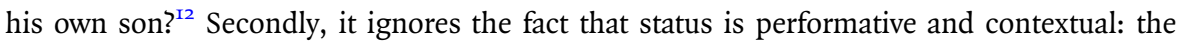
elements of one's status which are important change depending on the circumstance and on those with whom one interacts. A slave may be entirely subordinate to their master domestically but if they are acting as his business agent they may have a great deal of social spending power in the agora or on the docks. As Vlassopoulos has previously observed, one's parents' legal status could be crucial in court but 'for the majority of ordinary citizens this would rarely have been an issue'. ${ }^{\text {13 }}$

Keith Hopkins' analysis of social mobility among Roman elites is one of the few (and certainly the first) work of ancient history to explicitly engage with status inconsistency as an explanatory model for social mobility. ${ }^{\mathrm{I}}$ Interestingly, the most thorough recent engagement with this theory is content to use his multi-dimensional model when discussing social mobility but, in discussing social structure, follows the Weberian approach of Geza Alföldy. ${ }^{15}$ Unfortunately, although Alföldy appears to be aware of Hopkins' work, ${ }^{16}$ he does not engage with his arguments.

For Hopkins, a sociologist trained and working in the late 1950 s and early $1960 s,{ }^{17}$ the idea of articulating status in multi-dimensional terms was so unremarkable as to require no footnotes in his work. Although understandable, given the unanimity of this model's acceptance in the social sciences, this has meant that the few Roman social historians who have engaged with Hopkins treat his approach as the origin and final development of this concept, ${ }^{18}$ rather than as one stage in a developing sociological model.

Hopkins' model was actually overtaken, subsequent to its publication, by two major developments. The first was the Oxford Group for the Study of Social Mobility's division of status into social (institutionalised) and sub-social (interpersonal) elements, ${ }^{19}$ according to which some elements of status are recognised by one's whole society, while others are defined by personal interaction. The second was Pierre Bourdieu's argument that economic capital holds no inherent social value, but rather can be converted into

\footnotetext{
See discussion below.

3 Vlassopoulos (2009) 358.

Hopkins (1965).

Hope (2000) 135 and 144.

Alföldy (I985) 238 n. I69.

I7 See section 'A history of status (in)consistency' below, for the significance of this timing.

I8 Hope (2000) I44; Mennen (20II) Io; Alföldy (1985) rejects Hopkins' model.

I9 Again, see fuller discussion below.
} 
social capital 'at the cost of a more or less great effort of transformation'20 - i.e. different ways of disposing of economic capital will give a different return in terms of social capital. The clearest example of this in the ancient world is the greater prestige lent to investment in land over investment in trade, manufacture etc.

Ignorance of the first development leads to a vagueness in referring to 'social mobility', whereby it is used to describe a wide variety of social movements, many of which should not be considered true social mobility. The career mobility of wealthy elites following the cursus honorum, for example, would not be considered social mobility by the Oxford Group if it were not accompanied by a concomitant increase in the level of one's friends, associates, style of life etc. nor if it did not represent an intergenerational contrast (i.e. if it did not differ from their fathers' progress). Ignorance of the second often seems unproblematic as, for example, the property qualifications for certain positions in the Roman Empire translated economic capital directly into rank. However, not only would this only have been relevant to a tiny proportion of the population but it suffers from the same two issues as Kamen's work: privileging one particular aspect of social status (legal status, or institutionalised rank) through the privileging of the social viewpoint of one elite group and ignoring the performative nature of status.

Despite the flaws in Hopkins' model, it is still a better description of status than any produced by those who followed him. Unfortunately, his model does not seem to have gained currency as a model for articulating ancient Greek social structures. Indeed neither Finley, de Ste. Croix, nor Kamen engages in a dialogue with Hopkins' articulation of status - despite all appearing, from their bibliographies, to be aware of his work.

Many of the status issues which are being discussed in this article have recently been brought to the fore in Taylor and Vlassopoulos' Communities and Networks. ${ }^{21}$ Taylor, in particular, argues very successfully that one can best understand status and social mobility in the lower echelons of Athenian society in terms of the social capital endowed to members of social networks. ${ }^{22}$ Hopkins' theories (and, indeed, those explicated in this article) seem to be naturally complementary with Taylor and Vlassopoulos'. Many elements of status are determined by membership of social networks, and this is a particularly important way to observe the relative importance or lack of importance of institutionalised status elements (e.g. legal status) in specific circumstances (e.g. group religious dedications). However, while making very good use of Bourdieu and Granovetter, Taylor and Vlassopoulos' work does not engage with much of the mid twentieth-century sociological literature on status and this leads them to discuss all aspects of status as depending on social networks. Though discussing the interaction of different legal status groups is illuminating, we must not allow ourselves to forget that some status elements were determined not by membership of a common group but by some inherent virtue (e.g. attractiveness, ethnicity), individual action (style of life, use of

20 Bourdieu (I986) 252.

2 I Taylor and Vlassopoulos (2015).

22 Taylor (2015). 
leisure time, professional competency etc.) or institutionalised social norm (e.g. legal status). The model adumbrated in this article will knit together the network elements of status so successfully described in Taylor and Vlassopoulos' work with these other elements of status.

One of the few works to engage meaningfully with sub-societal elements of status is Edward Harris' Aeschines and Athenian Politics. ${ }^{23}$ The author is aware of a variety of modern sociological works and gives a very thoughtful exposition of the importance of lifestyle elements as indicators of membership of the demonstrably ambiguous Athenian kaloi kagathoi. His engagement with the sociological literature enables him to avoid the pitfall of conflating legal status with other elements of status. However, Harris' aim was to explicate Aeschines' origins, rather than to produce a new taxonomy of status. Thus, although he intelligently comments on the difficulty of equating wealth with status in Athens, he ultimately uses this as a means through which to problematise the inclusion or non-inclusion of individuals into the ranks of the kaloi kagathoi, rather than as a springboard to discuss the performativity of status.

\section{A new paradigm}

I propose a new theoretical framework around which ancient historians should articulate issues of status. The basic premise of this theory is very simple, that a person's social status is constructed from almost innumerable different factors: e.g. birth, career, legal status, religious positions or associations, magistracies, friends, family, attractiveness, ethnicity etc. Some of these factors will naturally interact while others are mutually independent. This theory holds that vertical movement of any one of these aspects will produce an inconsistency between that and other aspects of an individual's social status.

The utility of having an accurate theoretical model for ancient societies is twofold. First, there is inherent value in having an accurate descriptive model. If we are to understand features such as individual status, social mobility, social structures and societal change, it is helpful to be able to articulate them within an accurate descriptive framework. However, a model is only truly useful if it helps us to understand otherwise obscure or misunderstood features of society. This article will not attempt to illustrate every possible explanatory purpose of this model. I will, however, provide two case studies to demonstrate how the model can help us to elucidate otherwise obscure details on a societal and individual scale. I will start by applying the model to Lakedaimonian society in the Classical period and demonstrate how this helps us to understand why certain social movements within it were encouraged or resisted. I will then discuss the position of Pasion of Acharnai, and his son Apollodoros, in Athens and demonstrate how status (in)consistency can help us to understand not only their status but also certain issues with their lives and Athenian society. One of the key questions this article will seek to 
answer is why, in Greek society, some social movements were allowed or even encouraged, while others were not. It is worth mentioning that, although the article will demonstrate the utility of this theory to understanding and exploring status in the Greek world, the general framework is equally applicable to all historical societies.

\section{A history of status (in)consistency}

As early as 1944 sociologists critiqued existing social models (for example those of Marx, Weber, Gumplowicz, Ratzenhoffer and Oppenheimer) which viewed social status in terms of uni-dimensional hierarchies (largely based on economic status or power relationships). ${ }^{24}$ Within these early critiques a new model of status was posited, based on what has been variously described as status crystallisation, status (in)congruency, status (in)consistency or status stress. ${ }^{25}$ These new theories predicted that consistency or inconsistency between different elements of an individual's or group's status would be a causal factor in their attitudes and behaviour and the attitudes and behaviour of others towards them.

However, it was not until the early I950s that the predictive utility of this new multidimensional approach to status was given experimental validation. ${ }^{26}$ Stuart Adams was able to show that the status congruency of bomber crews in the US airforce was positively correlated to their performance. At roughly the same time, Gerhard E. Lenski, who gave the theory its best early theoretical framework, demonstrated that status crystallisation (i.e. high status congruency, or consistency) in Detroit was inversely correlated to a variety of liberal views and voting behaviours. Irwin W. Goffman's study of a rather larger sample from across the USA confirmed and expanded Lenski's earlier conclusions before Lenski himself showed that the theory could be applied to a number of countries across the industrialised world. The proposition received further support from Ringer and Sills' study of social attitudes in Iran - though they did not frame their work in the same theoretical terms. ${ }^{27}$ The exact findings of these studies are largely irrelevant to the ancient world; the crucial point here is that they were able to demonstrate not only that there were multiple independent elements of status, but also that the relative consistency or inconsistency of these elements was a key determinative factor in individual and group behaviour. By extension, they proved that uni-dimensional approaches were masking features which determined attitudes and behaviours. With the printing of Freedman et al.'s 1956 textbook, the multi-dimensional approach to status became the standard predictive model of sociological studies. ${ }^{28}$

\footnotetext{
24 Benoit-Smullyan (1944); Sorokin (1947); Kaufman et al. (1953).

25 All of these terms seem to have roughly equal utility. The current work uses status (in)consistency as it is the term used by Hope in his later theoretical formulation of the concept.

26 For what follows see Adams (1953); Lenski (1954) and (1967); Goffman (1957).

27 Ringer and Sills (1952).

28 Freedman et al. (1956).
} 
It was not until the I970s that the multi-dimensional model of status received its most complete theoretical formulation, with the work of the Oxford School for the Study of Social Mobility. ${ }^{29}$ In their discussion of social mobility they divided status into numerous, often mutually interactive, elements. In addition to this, the group divided the aspects of social status into two broad groups: (I) societal, or institutionalised, status and (2) sub-societal, or interpersonal, status. Societal status contains those aspects which affect how individuals interact with society as a whole; aspects such as legal status, priesthoods and magistracies might fit neatly into this category. Bourdieu would describe these as institutionalised forms of social capital. ${ }^{30}$ Sub-societal status is made up of aspects which govern one's 'style of life', in other words, how individuals interact with those they know: attractiveness, friendship, kinship, associations and use of leisure time would fit well into this group. Bourdieu might describe these as elements which aggregate to an individual's actual or potential resources of social capital. In the model of the Oxford Group, to achieve social mobility, rather than status inconsistency, one must experience a move in societal status and a concomitant movement in sub-societal status. Movements which do not fit these criteria are better described as a social movement (in one or more status element) rather than social mobility. The multi-dimensional model has been retained as a descriptive and predictive experimental tool throughout the last sixty years, ${ }^{3 \mathrm{I}}$ although often only implicitly.

\section{Status (in)consistency in the ancient world}

Although not an exhaustive list, Figure I makes an attempt to represent some of the elements which formed the social status of an individual in the ancient world (note that wealth is not included as a factor since, though it may be converted into forms of social status, it has no inherent social value). Many, though by no means all, of these are determined by membership of some kind of social group or network such as those described so successfully in Taylor and Vlassopoulos' recent volume. ${ }^{32}$

What is important is that there is a nexus of status elements which draw societal and sub-societal status in different directions. If one were to plot the 'status' of the individual onto a graph of all elements of social statuses, one would have to draw a different set of axes for each of these (often interrelated) status elements. The most important fact here is that the potential contrast between different elements of status would make it impossible to plot any given individual as a point on a spectrum of status. It would only

\footnotetext{
29 The following paragraph relies on Hope (I972). See also Matras (I980).

30 Bourdieu (I986).

3I See, for example, Kasl and Cobb (I967); Erickson, Pugh and Gunderson (I972); Erickson, Edwards and Gunderson (I973); Goldthorpe (I980); Erikson and Goldthorpe (I992); Keil, Armstrong-Stassen, Cameron, and Horsburgh (2000); Goldthorpe and Jackson (2007); Friedman (2014).

32 Taylor and Vlassopoulos (2015).
} 


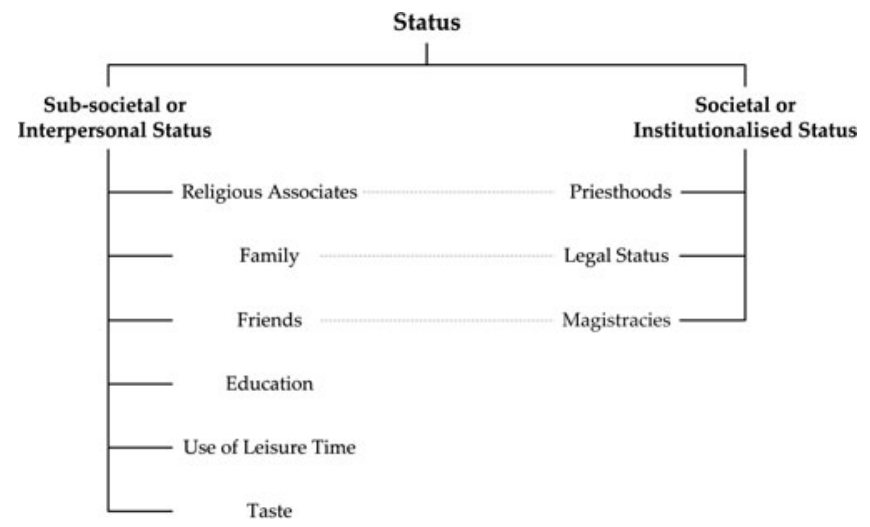

Figure I. Diagram of social status in (ancient) societies and some of the aspects thereof; after the Oxford Group for the Study of Social Mobility (Hope (1972)). Dotted lines indicate some obvious links between certain social and sub-social status elements.

be possible to plot one element of an individual's status on one of an almost infinite number of different spectra of status elements.

The diagram in Figure I divides elements of status into societal and sub-societal groups but also illustrates the interconnectivity of these two groups. Legal status, for example, might be (partially) defined by one's relationship to one's family. Equally, which magistracies and priesthoods are available to individuals might be delimited by their friends and religious affiliations.

As noted above, it was the opinion of the Oxford Group that in order to achieve social mobility, rather than status inconsistency, one must experience a move in societal status and a concomitant movement in sub-societal status. Thus, freedmen could become as influential and respected as they pleased, but their background might still prevent them from institutionalising these status elements within the magistracies and priesthoods of the freeborn elite. One might argue that Augustus' creation of the imperial priesthood relieved the pressure of this status inconsistency through allowing freedmen to institutionalise their social capital - although in earlier times Roman freedmen could, of course, institutionalise their social capital vicariously through their children. Equally, the act of enslaving foreign freepersons and transporting them into domestic slavery is true social mobility, as their decrease in legal and other institutionalised status elements is matched by a concomitant drop in their interpersonal status elements caused by their natal alienation and placement into a social situation of very limited privilege and prestige. ${ }^{33}$

This sort of inconsistency is apparent to those living in a hierarchical society and in such societies is felt to be threatening (this is why status stress is sometimes used as a synonym 
for status inconsistency). ${ }^{34}$ In particular, status inconsistency has been shown to contribute to reduced cooperation, effectiveness and group cohesiveness in small group experiments. ${ }^{35}$

The anger at powerful imperial slaves evident in Tacitus ${ }^{36}$ and his contemporaries and the mockery of the nouveau riche freedmen in Petronius are examples of this resistance to socially inconsistent individuals at Rome. Such aversion to the success of those from lowly backgrounds appears also to be rife in Athens; Apollodoros complains of his illreputation and ill-treatment stemming from his father's freedman status. ${ }^{37}$ Similarly, as I will explore below, social movements in Lakedaimon which resulted in status inconsistency were strongly resisted.

The alarming nature of status inconsistency means that any social movement can be thought of as threatening. For this reason, social movement is something many hierarchical societies seek to control. In these societies it is most often allowed only as a relief to other social pressures: manumission, for example, promises an amelioration of suffering for the enslaved population and thus alleviates the fears of the dominating group.

In order to demonstrate the descriptive and analytical value of this new model, I now turn to the two case studies mentioned earlier, namely an exploration of status descriptors in classical Lakedaimonian society, and a discussion of status issues in the lives of two famous Athenian social climbers, Pasion and Apollodoros.

\section{Social movement in classical Lakedaimonian society}

As I stated at the beginning of the article, this theoretical model has two advantages: first, it gives us a more solid theoretical framework for describing Greek society; second, it provides tools through which we can more easily understand the causes of certain social practices. In particular the theory helps us to understand why certain types of social movement are encouraged while others are resisted. In this case study I will demonstrate that we can best understand the organisation of the legal status groups of Lakedaimonian society and the movements between them by articulating these processes within the theoretical framework of status inconsistency. Here I will define legal status as an institutionalised title, the rights of which are juridically enforceable.

I start with two observations of classical Lakedaimonian society:

(I) We may describe Spartan society as having been made up of three major legal status groups: the Spartiates, the perioikoi and the helots. Besides these three major legal statuses were a plethora of legal statuses for which we have significantly less information and which, at least initially, probably made up a substantially smaller

34 Kasl and Cobb (1967).

35 Adams (I953); Exline and Ziller (I959); Litterer (I966).

36 E.g. Annals II.35, I3.2.

37 See my full treatment of Apollodoros' status below. 


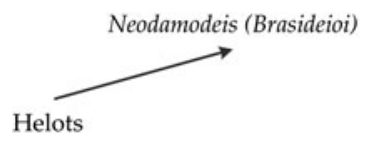

Nothoi

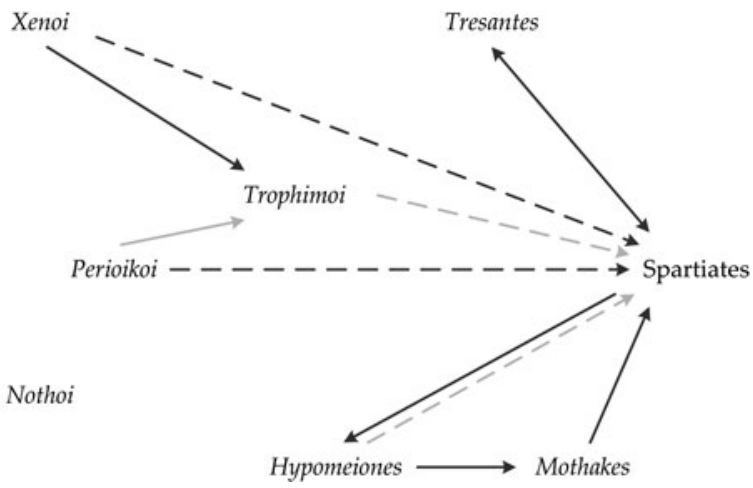

Figure 2. A diagram demonstrating possible movements between different legal-status descriptions in Lakedaimonian society: arrows represent direction of movement; solid black lines represent movements for which we can be certain; grey lines represent doubt in the possibility of the depicted movement; dotted lines represent movements which were only possible under the reformers of the third-/second-century crisis.

part of the population; these would include the neodamodeis (and the brasideioi), hypomeiones, nothoi, mothakes, partheniai, hirees, trophimoi, mothones, tresantes etc. In addition, although also known as the homoioi, 'similars', there were also a number of apparently divisive status descriptors within the Spartiate order, many or all of which carried some legal privileges: for example, the gerontes, hippeis, hirees and (possibly) the kryptoi and heraklids. Included within these are legal statuses for which we have a name but no absolute certainty of the meaning of that name (e.g. hypomeiones). ${ }^{38}$

(2) Individuals could not move between any two of the three major legal statuses. A move which caused them to leave any one of those legal statuses would result in them joining one of the minor legal statuses (see Figure 2), i.e. freed helots probably became neodamodeis, Spartans who lost their citizen status might have become hypomeiones.

Why was social movement in Sparta made from major into minor legal statuses rather than between the major legal status groups? We can better understand this question by saying instead that the statuses of social movers are specific descriptions of legal pathways rather than equating them to the statuses of existing legal status groups.

I would also argue that this is because Sparta was an intensely status-conscious society. This will require some proof. Even those who do not accept the model of a Sparta in

$3^{8}$ Of course, many societies of the Mediterranean had numerous status titles and the intention here is not to argue for this being a unique or distinguishing feature of Spartan society, but merely to enumerate these titles for the following discussion. 
constant fear of its subordinate populations would say that the Spartans were acutely aware of the status issues in their own society:

But the Greeks, when they had divided the spoils at Plataea, buried each contingent of their dead in a separate place. The Lakedaimonians made three tombs; there they buried their hirees, among whom were Posidonius, Amompharetos, Philokyon and Kallikrates. In one of the tombs, then, were the hirees, in the second the rest of the Spartans, and in the third the helots. This, then, is how the Lakedaimonians buried their dead. The Tegeans, however, buried all theirs together in a place apart, and the Athenians did similarly with their own dead. So too did the Megarians and Phliasians with those who had been killed by the horsemen. ${ }^{39}$

In highlighting the Lakedaimonians as the only polis to separate the dead of the battle into different legal status groups, Herodotus makes plain their status consciousness. In the case of the helots, one could hypothesise that the Spartans were the only contingent to have slaves die in the conflict. However, the hirees were almost certainly priests, or members of a religiously distinct and honoured group..$^{40}$ It is rather more difficult to imagine that other poleis lost no one who could be distinguished in such a way.

Thucydides provides further evidence in the sending home of the Athenian contingent in the Messenian revolt due to dangerous suggestions of solidarity:

The Lakedaimonians, when assault failed to take the place, apprehensive of the enterprising and revolutionary character of the Athenians, and further looking upon them as of alien extraction, began to fear that if they remained, they might be tempted by the besieged in Ithome to attempt some political changes. ${ }^{4 \mathrm{I}}$

While this text may also be used to demonstrate Athenian status consciousness, it is not my intention here to compare or contrast Athenian and Lakedaimonian practice and thought, but merely to elucidate the Lakedaimonian. The Lakedaimonians in this passage demonstrate their acute awareness of tensions between social groups divided by their legal status titles. Finally, we may add the words put in the mouth of one of Kinadon's co-conspirators by Xenophon:

... helots, neodamodeis, hypomeiones and perioikoi; for whenever among these classes any mention was made of the Spartiates, no one was able to conceal the fact that he would be glad to eat them raw. ${ }^{42}$

\footnotetext{
39 Herodotus 9.85. All translations are taken (sometimes adapted) from the Loebs.

40 Den Boer (1954) 288-300; Kennell (I995) I5; Toher (1999) II8-26; Flower and Marincola (2002) 255-6; Gilula (2003) 8I-7; contra Makres (2009).

4I Thucydides I.IO2

42 Xenophon, Hellenica 3.3.6
} 
Although we may question whether such a sentiment was actually pervasive, the passage strongly suggests that status division was an important part of the social discourse of Sparta in Xenophon's day. Indeed, he was of the opinion that the Spartans showed such deference to rank that they stood 'more in awe of their leaders than of anyone else' (Xenophon, Respublica Lacedaemoniorum 2.10).

It is not a stretch to say that a society peculiarly aware of social status should also be peculiarly aware of status inconsistency. If one is acutely aware of a person's social status one must naturally be aware of different elements of that individual's status. If those elements are not consistent it can be apparent to any observer and it will be blatantly apparent to the socially astute internal observer.

I have already stressed that many societies seek to control social movement and use it to relieve social pressures. Sparta is no different: for example, using manumission of helots to relieve their need for fighting men. Equally, failure to live up to the belief in common contribution would, it seems, cause one to be ejected from the homoioi, thus relieving the social pressure of endangering the ideological equality of the Spartiate (ideological equality here is not to be confused with any degree of actual egalitarianism).

However, in allowing those sorts of changes of legal category, society is allowing a change in an individual's societal status. But this does not necessarily engender any movement in an individual's sub-societal status; their kin, friends, birth etc. could remain the same. To move, for example, a helot into the perioikic status group, or to demote a Spartan into this same group, would cause dissonance between their social and subsocial statuses. To illuminate this we can consider two contrasting examples of social mobility from and into the Spartiate class. First of all, those accused of cowardice in battle, the tresantes ('tremblers'):

For such men are not only debarred from every office, but intermarriage with any of them is a disgrace, and anyone who meets them may strike them if he pleases. Moreover, they are obliged to go about unkempt and squalid, wearing cloaks that are patched with dyed stuffs, half of their beards shaven, and half left to grow. ${ }^{43}$

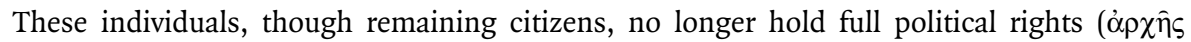

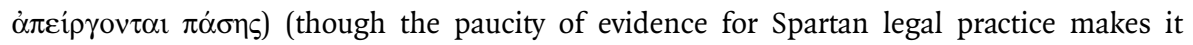
impossible for us to tell how this was enforced). ${ }^{44}$ What is interesting from our perspective is that, in combination with this, they have enforced upon them a concomitant decrease in their sub-societal status (enforced, we might assume, on a subsocietal rather than institutionalised level). While being disbarred from political office, it is correspondingly made socially difficult (if not impossible) for them to interact on their previous social level with other citizens. It was not generally possible for these individuals 
to regain full citizen rights, and the fact that marrying a citizen woman was made difficult for them meant that it was not easy for their children to attain such rights.

The contrasting example is provided by the mothakes. These appear to be the children of hypomeiones: those disenfranchised for failing to maintain their contributions to the syssitia. ${ }^{45}$ Yet these hypomeiones are ideologically challenging. Although they are disenfranchised which decreases their legal status - and, by ejection from the syssitia, experience also a certain decrease in their sub-societal status, in all other regards their sub-societal status remains unaffected. There is no reason they should not continue to interact with their kin, friends and business contacts just as they had before being disenfranchised:

Kallikratidas, Gylippos and Lysander in Lakedaimon were called mothakes. This was the name of the foster-brothers (syntrophoi) of the affluent, whom their fathers sent with them to compete in the gymnasia. The man who made this arrangement, Lykourgos, granted Lakedaimonian citizenship to those who kept to the boys' agoge. ${ }^{46}$

Thus, to relieve the pressure of status inconsistency, the sons of such individuals could be foster-educated with the children of wealthier households. ${ }^{47}$ The status inconsistency experienced when disenfranchising these Spartiates is relieved when their sons pass through the education system and are re-elevated to full citizen status. Additionally, if Stephen Hodkinson is correct to argue that the boys would later become part of the retinue of their foster-brother, ${ }^{48}$ these re-enfranchised Spartans strengthened their subsocietal connection to the Spartiate group and created a durable form of social capital.

That, I think, helps us to explain why movement between the major social groups was not generally allowed in this, very status-conscious, polis. Helots and Spartiates were not allowed to become perioikoi because in the eyes of the Spartan they could not become perioikoi. In the case of the helots, this was because they were, as Ducat has put it, les inférieurs par excellence. ${ }^{49}$ They might achieve the legal rank but other elements of their status would be inconsistent with this. Therefore, they created legal statuses which were accurate social descriptors, delineating, as they did, not just the status but the path to that status and thus illuminating not just societal but sub-societal elements of an individual's status.

This awareness of status inconsistency also helps us to understand another rather strange feature of Spartan history: the question of why it essentially allowed itself to die through the famous Spartan oliganthropia. If the Spartiates were aware of the uses of social engineering - and we see that in other situations they were very aware of the utility of social movement - why did they not allow aspirational perioikoi, foreigners, or indeed

45 See n. 47.

46 Aelian, Varia historia 12.43

47 See Hodkinson (2009) 355 for the accuracy of Aelian in this matter.

48 Hodkinson (I997).

49 Ducat (I974) I453. 
helots to join their ranks and maintain the ruling elite ${ }^{50}$ The answer to this question is the same as to the one above: because, in the eyes of the Spartans, these 'lessers' could not become Spartiates. Only the dire straits of the late third century could cause them to overlook this fact..$^{\mathrm{I}}$

I began this section with two observations of classical Lakedaimonian society, (I) that Spartan society was made up of three major legal status groups (Spartiates, Perioikoi, helots) and a number of minor ones; and (2) that an individual could move only from a major to a minor group (or vice versa), not from one major group to another. I would add to this a further observation based on my own analysis:

(3) The legal status titles which were used to distinguish these groups represented descriptions of social pathways, not just descriptions of current status.

It is perhaps interesting to note that there is little, if any, evidence for changes to this system before the crisis of the late third century. The social inertia of the Lakedaimonian populace appears to have created so much resistance to change that even in periods of apparent crisis such as, for example, the one following the defeat at Leuctra in 37I there was no apparent desire to engender significant structural changes to the system. This is not to say that society remained static, but merely that its structural underpinnings (as observed above) remained constant.

\section{Pasion and his legacy}

With the utility of this model thus demonstrated on a societal scale, it is useful to do so on a personal scale. The lives of Pasion of Acharnai and his son Apollodoros sketch one of the starkest and best-documented examples of social movement in Athenian history. Marloes Deene has given an extremely lucid account of the current thinking on their social movements, and it is not my intention to give a narrative of their careers, a task which Trevett has performed admirably, but merely to elicit details and stages of their lives which will be of relevance to the later discussion..$^{2}$

Pasion, a (probably) Phoenician slave, came to Athens at some time in the late fifth century and was bought by two (probably) citizen bankers. ${ }^{53}$ Having done a (presumably) impressive job managing their bank, he was freed and by 394/393 had gained ownership of the bank itself. His wealth allowed him to become a generous civic benefactor, and his

\footnotetext{
50 Although foreigners could be fostered through the Spartan education system, as we see in Agesipolis' army (Xenophon, Hellenica 5.3.9) and perhaps Xenophon's own sons (Diogenes Laertius 2.54), there was no question of them gaining citizenship.

5I A re-evaluation of the changes in this later period, within the theoretical framework laid out in this essay, would be fruitful but lies outside the remit of the current work.

52 Deene (20II); Trevett (1992).

53 For the discussion from which this paragraph is drawn see Trevett (1992) I-9.
} 
gift of I,ooo shields and five triremes at points of particular need for the Athenians apparently secured him naturalisation as a citizen, (probably) around 386.54 Upon his death, in 370/369, he bequeathed to his two sons a significant patrimony: besides the bank itself, substantial urban and rural property holdings, and the shield factory from which he had supplied the Athenians with the aforementioned shields. ${ }^{55}$

The life of Pasion's eldest son, Apollodoros, from whose speeches we gain much of our evidence about the two men's lives, followed a very different trajectory. Born into one of the wealthiest and best-connected families in the polis, he adopted the lifestyle of the elite citizen. Upon his father's death he moved from the family home in Piraeus to a house in the country, and his life is perhaps best defined by the elite occupations of leisure, liturgy, and politics. ${ }^{56}$

These details are well known and are not under dispute. Here I will demonstrate the utility of the multi-dimensional model in answering three questions about these two men, and the society in which they lived. First, what light can the model shed on the status of apophora-bearing slaves in Athens (a group to which Pasion clearly belonged before his emancipation and which Kamen describes as 'privileged' slaves)? ${ }^{57}$ Second, why is it that freedmen bankers, such as Pasion, tend to have found it easier than other metics to gain citizenship? Third, why is it that Apollodoros, despite his servile ancestry, felt able to direct vitriolic attacks against Phormion on the basis of his status as a freedman?

The common view of these 'privileged' slaves, those who were allowed significant freedom of movement, industry and expenditure by their masters (be they individuals or the polis), is best summed up by Trevett's comments on slaves in finance, trade and industry:

There is some evidence that Athenian slaves could do quite well for themselves, and that particularly in the commercial world of the Piraeus the usual sharp line between slave and free became blurred..$^{8}$

The idea that slaves engaging with citizens and metics in business should blur the line between slave and free stems from the uni-dimensional approach to status. ${ }^{59}$ The argument goes that if a slave engaged with a free person in any relationship other than dependent subservience then he was acting in a way that was contrary to his legal status. However, this is demonstrably not true. The business deals which slaves engaged in were made with funds or goods which were the legal property of their master. ${ }^{6}$ Slaves had no

54 Davies (I97I) 430.

55 Davies (I97I) 43I-4.

56 Trevett (I992) 9-I7.

57 Kamen (2013) I9-31.

58 Trevett (I992) I55.

59 Cf. Lewis (forthcoming) chapter 2.

6o David Lewis has done an excellent job of laying out the empirical evidence for this in chapter I of his forthcoming monograph on ancient slavery. 
legal recourse through which to enforce their possession of their de facto wealth or property. The relationships they built at the quayside or the workshop did not and could not threaten their masters' rights to dispose of them and their possessions in any way they might wish (beyond the normal protections afforded to slaves). Thus, the distinction between these legal statuses was never blurred, except in the sense so successfully described by Vlassopoulos: that status could be, and often was, difficult to observe, or prove, and therefore statuses could appear ambiguous. ${ }^{6 \mathrm{r}}$

The reason why actually clear legal divides appear blurry is due to the performativity of status. In conducting business in the bank, workshop or quayside, the slave engaged with, and related to, freemen on the basis of sub-societal status aspects. Non-institutionalised elements of status came to the fore: trustworthiness, friends, associates etc. Here, the slave's legal status is irrelevant. Interestingly, Trevett seems to be aware later in the paragraph that these relationships are dealing with elements of status that were not directly related to institutionalised, juridically defined limits:

Nor should we exaggerate the privileges afforded even to skilled slaves: an opponent of Pasion later showed no compunction in demanding that Kittos, who acted as chief cashier of his bank, be surrendered for interrogation under torture (Isoc. 17. 13.). ${ }^{62}$

We may contrast this with the concluding words of Kamen on 'privileged' slaves:

Privileged slaves, then, were on the cusp of freedom: they held a number of rights, and manumission was actually attainable for them, given sufficient accumulated income ... By possessing more wealth and privileges than poor, juridically free citizens, these slaves must have implicitly called into question the value of 'freedom', a concept assigned tremendous importance by the Greeks. In this way, their very existence challenged any neat ideas about free versus slave status. ${ }^{63}$

It is not at all clear to me what 'rights' Kamen is referring to here (in the sense Tony Honoré has defined: of 'rights' as a formal legal category which implies enforceability). ${ }^{64}$ The only example Kamen presents of a slave appealing to law is that of the public slave Pittalakos taking two citizen attackers of his to court for an assault on him (Aeschines r.62). However, it is not at all clear from the passage that he was still a slave at the time of the events. ${ }^{6}$ Aeschines was happy to describe him as 'a slave-fellow who is the property of

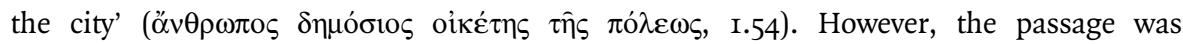
constructed as an attack on Pittalakos' character. As we will see in the case of

\footnotetext{
6I Vlassopoulos (2009).

62 Trevett (1992) 155.

63 Kamen (2013) 3 I.

64 Honoré (1987).

65 Indeed, Fisher's commentary ultimately concludes that he was probably a freedman: Fisher (200I) I90-I.
} 
Apollodoros later in this article, Greek orators were more than happy to describe freedmen as slaves when attempting to besmirch their character. All the other 'rights' attributed to them appear to be benefits allowed to them at the discretion of their masters rather than anything legally enforceable, as 'rights' would suggest.

Could these advantages in sub-legal status terms threaten the concept of freedom? I would argue that they could not. A slave's body was still not their own and could, unlike the body of a freeman, be mistreated by its master and demanded for mistreatment by the court. The elements of status which were inconsistent with the slaves' low legal status were sub-societal, and non-institutionalised, and could not, therefore, constitute a threat to juridically designated order. Yet it is clear from the constant references to their origins in the speeches of Apollodoros and Phormion's advocate that there was some unease with this inconsistency (see below). ${ }^{66}$

I turn now to the second question: why, among all wealthy metics, were bankers disproportionately likely to be awarded citizenship $?^{67}$ A discussion of the precise nature of Pasion's status after his manumission can help us to answer this question. J. K. Davies described this commonly observed phenomenon in the most succinct manner:

It rather looks as if it was mainly bankers, rather than other metic entrepreneurs, who were able to amass a sufficient investment in public goodwill to carry them across the social gulf which separated them from the citizen body. ${ }^{68}$

Trevett's explanation is more overtly mercenary than Davies' Bourdieurian 'investment in public goodwill'. He baldly asserts that bankers tended to be the only metics rich enough to afford 'acts of civic benefaction on a sufficiently grand scale to gain the citizenship in return'. ${ }^{69}$ Trevett may be right that it was sheer wealth which caused this preponderance of bankers in the ranks of naturalised citizens, and gaining naturalisation undoubtedly was an expensive business. Perhaps for this reason, Kamen is happy to follow this line. ${ }^{70}$

However, the pecuniary explanation does not fully account for the fact that buying one's way into the citizenship was not just a measure of wealth but was also indicative of a desire to expend that wealth in such a way as to gain recognition of public service from the politai. We could ask whether wealthy foreign traders might not wish to spend their money in such a way because they were contented with citizenship of their home polis (a natal bond which freedmen bankers could not claim). I note again that economic capital is not status but merely a tool that can be utilised in ways which build social capital.

66 The potential social pressure induced by this inconsistency across Athenian society would be a fruitful avenue for further study though space prevents me from doing so here.

67 Though, again, prohibitive in the current context, a more general study of the statuses of those awarded citizenship at Athens (listed in Osborne's ( $198 \mathrm{I}-3$ ) four volumes on the issue) would be worth thorough study.

68 Davies (I98I) 66.

69 Trevett (I992) I6r.

70 Kamen (2013) 8r. 
Further, I would ask the question of whether there even was a 'social gulf' which separated Pasion from the rest of the citizenry. In his formulation of the status of the Athenian elite, Josiah Ober certainly believed so:

\begin{abstract}
The standing of an Athenian in the eyes of his fellows and his ability to influence their actions were certainly based in part upon the wealth he controlled. But there were very wealthy (and highly educated) persons living in Athens who were not citizens. Without citizenship, they were denied the right to participate in the political process of the state. Since political rights were demonstrably important, those denied citizenship - metics, slaves, and women - could not be considered members of the highest status groups of Athenian society, even if they controlled a great deal of property. ${ }^{71}$
\end{abstract}

However, this interpretation, as also those of Davies, Trevett and Kamen above, is based upon one indicator of social standing: legal status, and the availability of money to buy into that indicator. However, if we view status in multi-dimensional terms, Pasion's status was not wholly distinct from that of the elite male citizen. Certainly Pasion's legal status as a freedman and metic was distinctly sub-elite. Thus, in institutionalised terms, prenaturalised Pasion could, as Ober correctly suggests, not be considered a true member of the elite. However, were these institutionalised status elements consistent with his subsocietal status elements? Pasion clearly had friends and clients among the highest echelons of Athenian society (e.g. Agyrrius of Collyte, mentioned at Isocrates 17.3I, and Timotheus, son of Conon, repeatedly mentioned in [Demosthenes] 49). ${ }^{72}$ Pasion's sons would become significant members of the liturgical class and Pasion himself acted as a de facto member of this class - despite not being able, as a freedman, to avail himself of its institutionalised titles. Equally, as Trevett has inferred from Isocrates 17 , bankers were 'respectable and respected figures'.$^{73}$ The speaker of Demosthenes $3^{6}$ also expects the dikasts to believe that trustworthiness was an attribute which could be naturally associated with the successful banker (36.44). This profession seems to have held some degree of prestige.

It is difficult to say a great deal more about Pasion's style of life, but he certainly had the disposable income available to conduct himself socially in a manner befitting a wealthy citizen. ${ }^{74}$ Indeed, we may at least guess that his friendships with elite citizens involved the sort of reciprocal dining, gift giving and favours which attended such relationships in the Greek world. This relationship is perhaps best attested by Pasion's ascription to the deme of Acharnai, rather than into Piraeus, his home. If Davies is correct in his

7I Ober (1989) 248-9.

72 See Trevett (1992) 156-8 on Pasion's influential citizen friends.

73 Trevett (1992) 159.

74 We can only guess at the extent to which Pasion and his son were integrated into the religious life of their deme, and the polis in general, as discussed by Wijma (2014). 
suggestion that this was due to the sponsorship of Pythodoros of Acharnai (a citizen of the liturgical class) and that Pythodoros' grandson claimed friendship with Apollodoros some thirty years later, this demonstrates close and lasting ties between the two families ${ }^{75}-$ indicative, almost certainly, of a close bond between the earlier pair.

Thus, the only sub-societal status elements we are left with which are distinctly sub-elite are Pasion's servile origins and his possible foreign extraction (two obviously intertwined features). David Whitehead has suggested that both of these characterisations, though they could be used as insults, tended to be a consideration secondary to the position of the individual as a metic. ${ }^{76}$ Perhaps the only confirmation of this we can draw from Pasion's example is that it did not prevent him from gaining substantial respect and friendship among the citizen population, nor did it prevent him from joining their ranks.

We may fairly safely say, then, that while Pasion's legal status was comparatively lowly, his sub-societal status was much as that of an elite citizen. The institutionalised and subsocietal elements of his status were inconsistent. This may well be representative of freedman bankers in general. Viewing status in this way illustrates that the apparent leap across the 'social gulf' in naturalisation was, in fact, status crystallisation (the creation of status consistency). His elevation to the citizenry brought the two broad groups of his status elements into line. This was a relief to the status inconsistency which we may posit was strenuous in social relations.

I should like to suggest one final indication of Pasion's naturalisation as an act of status crystallisation, rather than social mobility. This is the lack of evidence for any change in his style of living after his naturalisation, as Trevett has observed: 'He continued to work at the bank and to live in the Piraeus until his death. ${ }^{, 77}$ It seems odd, then, that Trevett is happy to agree with Claude Mossé's words:

La plupart de ces 'nouveaux riches' investissaient leur fortune dans l'achat de bienfonds, la constitution d'un 'patrimonie' le élevant dans l'échelle sociale. ${ }^{78}$

Although, as Trevett himself says, ${ }^{79}$ the buying of land 'signalled and confirmed' Pasion's citizen status, it cannot, as Mossé is suggesting, act as driving towards a status that, we have seen, Pasion already held in every regard which was possible for him. It is far better to ascribe Pasion's actions to the security which was offered by mixed investment in landholding and other forms of investment: a mixture which appears to have been the economic and social norm in his time. ${ }^{80}$ 
I turn now to my third and final question: why did Apollodoros, himself of fairly recent slave stock, feel able to direct vituperative anti-slave rhetoric at his opponent and father in law, Phormion? In Apollodoros' Against Phormion he repeatedly attacks Phormion as an exslave and, indeed, as an actual slave ([Demosthenes] 45.73-86). Yet, as Demosthenes 36 makes quite clear, few in the audience can have been unaware of Pasion's status as a freedman. Indeed, in the same section of Apollodoros' speech, as he attacks Phormion's past he is happy to humble himself to the citizens in reminding them of his duties as a naturalised citizen ([Demosthenes] 45.78).

Explanations of his vitriol tend to focus on psychological causes. M. J. Osborne posits that Apollodoros' attacks on Phormion's servile and barbarian origins stem from 'bitterness [springing] in large measure from consciousness of his own origins' ${ }^{8 \mathrm{I}}$ while Trevett attributes his motivations to personal animus: 'he hated his stepfather for marrying his mother, and resented his wealth and success'. ${ }^{82}$ What these two explanations share is the idea that the attacks are in some way irrational: that they could not have been carefully planned appeals to the prejudices of the Athenian dikasts. However, as Whitehead has suggested, the bitter attack on Phormion's origins 'does demonstrate the depth of prejudice available to be drawn on when required'. ${ }^{83}$

A multi-dimensional approach to Apollodoros' and Phormion's comparative statuses is helpful in drawing out the calculation behind Apollodoros' statements. Phormion was a freedman of Pasion, a naturalised citizen and a successful banker in his own right. ${ }^{84}$ It is thus extremely difficult to draw any substantive differences between his status, and that of Apollodoros' father. Indeed, the speaker in Demosthenes 36 is keen to emphasise this similarity $(36.45-8)$. Yet he goes out of his way not to describe Apollodoros as in any way slavish or to associate his status with that of a freedman. The speaker, in fact, insists that in comparison to Apollodoros Phormion's manner of life is far more similar to that of Apollodoros' father (36.3I) and repeatedly refers to his position as a man of commerce. $\mathrm{He}$, like Pasion, is a foreign-born banker, unable, due to inexperience, to speak for himself in the courts, despite having the right to do so (36.I). Although he praises Phormion's services to the polis and to many of its citizens (36.57), he stops short of claiming the sort of liturgical and choragic expenditure of which Apollodoros is able to brag. Apollodoros, rather, is attacked for his extravagance $(36.8,52$ etc.): the trope criticism against members of the liturgical class (Demosthenes 2I.I33, I58; 48.55; Andocides 4.I4; Aeschines I.I3r.). Apollodoros had, since before his progression to manhood, been a citizen of Athens. He was married to a citizen woman ([Demosthenes] 45.55, 59.2), and lived in the Athenian countryside ([Demosthenes] 53.4). Indeed the speaker of Demosthenes 36 describes as 'insanity' the idea that either Apollodoros or Phormion should be considered the property of their ex-masters, or father's ex-masters

\footnotetext{
8I Osborne (I98I-3) III.I96.

82 Trevett (1992) 175 .

83 Whitehead (1977) ir6.

84 Davies (1971) 435-7.
} 
(36.48). Yet Apollodoros' natal origins were servile and he is unashamed of referring, although humbly, to his origins as a metic ([Demosthenes] 45.78). He acted, in every observable respect, in the manner of a public Athenian citizen (Demosthenes $36.8,45):^{85}$ as I phrased it before, a life of leisure, liturgy and politics. Phormion's life, contrastingly, belonged to the commercial world of Piraeus. These were the aspects of his status which allowed him to be attacked on the basis of his servility, but did not allow Phormion's friend to direct the same attack back at Apollodoros. Though the legal statuses of the two men were nominally identical (both were naturalised citizens), their relative styles of life exposed Phormion to the sort of attack which he could not direct back at his attacker (this is not to say that in situations where Apollodoros' opponent could claim greater antiquity of status their positions could not be reversed, as appears to be the case with Polykles in [Demosthenes] 50).

\section{Conclusions}

I stated at the start that the complexity of the term 'status' defies simple definition. Indeed, much of the criticism I have made of existing scholarship in this area surrounds the imprecision of language stemming from previous simple definitions. I would encourage future work in this area to be explicitly aware of the multi-faceted, contextual and performative nature of status. Thus, I suggest instead the definition of the relative respect and deference accorded to an individual in any given situation.

The development of multi-dimensional approaches to status in the social sciences in the I940s and I950s and their later development have shown both the predictive utility of such models in observations of modern societies and the difficulties with conflation of status elements from which previous uni-dimensional approaches suffered. This essay has shown the value of such a multi-dimensional model in the Greek world both in accurately describing social status and in explaining the behaviour of past individuals and societies. It is key that we judge past status on the basis of its almost innumerable facets and give proper recognition to both institutionalised and sub-societal elements. It is particularly important not to conflate or confuse elements which describe an individual's style of life with more easily distinguished elements such as origins and legal status, or to underplay the importance of these lifestyle elements.

\section{Works cited}

Adams, S. (I953) 'Status congruency as a variable in small group performance', Social Forces 32.I, I6-22. Alföldy, G. (1985) The social history of Rome, New York.

Benoit-Smullyan, E. (I944) 'Status, status types, and status interrelations', American Sociological Review 9.2, I5I-6I. 
Bourdieu, P. (Ig86) 'The forms of capital', in J. Richardson (ed.), Handbook of theory and research for the sociology of education, New York, 24I-58.

Davies, J. K. (I97I) Athenian propertied families: 600-300 BC, Oxford.

(I98I) Wealth and the power of wealth in Classical Athens, Salem, NH.

Deene, M. (20II) 'Naturalized citizens and social mobility in classical Athens: the case of Apollodoros', Greece \& Rome 59, 159-75.

Den Boer, W. (I954) Laconian studies, Amsterdam.

Ducat, J. (I974) 'Le mépris des Hilotes', Annales 29.6, I45I-64.

(2006) 'The Spartan 'tremblers', in S. Hodkinson and A. Powell (eds.), Sparta and war, Swansea, I-55.

Erickson, J. M., Edwards, D. and Gunderson, E. K. (1973) 'Status congruency and mental health', Psychological Reports 33, 395-40I.

Erickson, J. M., Pugh, W. M. and Gunderson, E. K. (1972) 'Status congruency as a predictor of job satisfaction and life stress', Journal of Applied Psychology 56.6, 523-5.

Erikson, R. and Goldthorpe, J. (1992) The constant flux: a study of class mobility in industrial societies, Oxford.

Exline, R. V. and Ziller, R. C. (I959) 'Status congruency and interpersonal conflict in decision-making groups', Human Relations I2, I47-62.

Finley, M. I. (1973) The ancient economy, Oakland, CA.

(I98I) Economy and society in ancient Greece, London.

(1983) Politics in the ancient world, Cambridge.

Fisher, N. (200I) Aeschines: Against Timarchos, Oxford.

Flower, M. and Marincola, J. (2002) Herodotus Histories: book ix, Cambridge.

Freedman, R. et al. (1956) Principles of sociology: a text with readings, New York.

Friedman, S. (2014) 'The price of the ticket: rethinking the experience of social mobility', Sociology 48.2, 352-68.

Gilula, D. (2003) 'Who was actually buried in the first of the three Spartan graves (Hdt. 9.85.I)? Textual and historical problems', in P. Derow and R. Parker, (eds.), Herodotus and his world, Oxford, $73-88$.

Goffman, I. W. (I957) 'Status consistency and preference for change in power distribution', American Sociological Review 22.3, 275-8I.

Goldthorpe, J. H. (1980) Social mobility and class structure in modern Britain, Oxford.

Goldthorpe, J. H. and Jackson, M. (2007) 'Intergenerational class mobility in contemporary Britain: political concerns and empirical findings', British Journal of Sociology 58.4: 525-46.

Hansen, M. H. (I99I) The Athenian democracy in the age of Demosthenes: structures, principles, ideology, Oxford. Harris, E. M. (1995) Aeschines and Athenian politics, Oxford.

Hodkinson, S. (1997) 'Servile and free dependants of the classical Spartan oikos', in M. Moggia and G. Cordiano (eds.), Schiavi e dipendenti nell'ambito dell'oikos' e della 'familia', Pisa, 45-7I.

(2009) Property and wealth in classical Sparta, Swansea.

Honoré, T. (1987) Making law bind: essays legal and philosophical, Oxford.

Hope, K. (ed.) (I972) The analysis of social mobility: methods and approaches, Oxford.

Hope, V. (2000) 'Essay five: status and identity in the Roman world', in J. Huskinson (ed.), Experiencing Rome: culture identity and power in the Roman Empire, London, $125-52$.

Hopkins, K. (1965) 'Élite mobility in the Roman Empire', Past \& Present 32, I2-26.

Hunter, V. J. (2000) 'Introduction: status distinctions in Athenian law', in V. J. Hunter and J. C. Edmundson (eds.), Law and social status in classical Athens, Oxford, I-29.

Jones, A. H. M. (1957) Athenian democracy, Oxford.

Kamen, D. (2013) Status in classical Athens, Princeton.

Kasl, S. V. and Cobb, S. (1967) 'Effects of parental status incongruence and discrepancy on physical and mental health of adult offspring', Journal of Personality and Social Psychology 7.2.2, I-I5.

Kaufman, H. F., Duncan, O. T., Gross, N. and Sewell, W. H. (I953) 'Problems of theory and method in the study of social stratification in rural society', Rural Sociology I8.I, I2-25. 
Keil, J. M., Armstrong-Stassen, M., Cameron, S. J. and Horsburgh, M. E. (2000) 'Part-time nurses: the effect of status congruency on job attitudes', Applied Psychology: An International Review 49.2, 227-36. Kennel, N. M. (I995) The gymnasium of virtue: education and culture in ancient Sparta, Chapel Hill.

Kron, J. G. (I996) 'Landed and commercial wealth at classical Athens 500-300 BC', PhD thesis, University of Toronto.

Lenski, G. E. (I954) 'Status crystallization: a non-vertical dimension of social status', American Sociological Review 19.4, 405-13.

(I967) 'Status inconsistency and the vote: a four nation test', American Sociological Review 32.2, 298-30I.

Lewis, D. (forthcoming). Greek slave systems and their Eastern neighbours: a comparative study, Oxford.

Litterer, J. A. (I966) 'Conflict in organization: a re-examination', Academy of Management Journal. 9·3, I78-86.

MacDowell, D. M. (I986) Spartan law, Edinburgh.

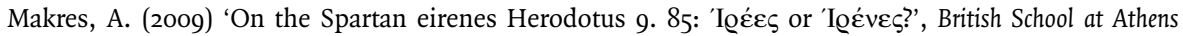
studies. Volume xvI: Sparta and Laconia: from prehistory to pre-modern, I87-94.

Matras, J. (I980) 'Comparative social mobility', Annual Review of Sociology 6, 40I-3I.

Mennen, I. (20II) Power and status in the Roman Empire, AD 193-284, Leiden.

Mossé, C. (1962) La fin de la démocratie athénienne: aspects sociaux et politiques du déclin de la cité grecque au iv siècle avant J.-C., Paris.

Ober, J. (I989) Mass and elite in democratic Athens, Princeton.

(I99I) 'Aristotle's political sociology: class, status, and order in the Politics', in C. Lord and D. K. O'Conner (eds.), Essays on the foundations of Aristotelian political science, Berkeley, II2-35.

Osborne, M. J. (I98I-3) Naturalization in Athens, 4 vols. in 3, Brussels.

Patterson, O. (1985) Slavery and social death: a comparative study, Cambridge, MA.

Ringer, B. B. and Sills, D. L. (1952) 'Political extremists in Iran: a secondary analysis of communications data', Public Opinion Quarterly 24.4, 689-70I.

Sorokin, P. A. (1947) Society, culture, and personality, New York.

Ste. Croix, G. E. M. de ( 1983$)$ The class struggle in the ancient Greek world from the Archaic Age to the Arab conquests, Ithaca, NY.

Taylor, C. (2015) 'Social networks and social mobility in fourth-century Athens', in Taylor and Vlassopoulos (2015) 35-53.

Taylor, C. and Vlassopoulos, K. (eds.) (2015) Communities and networks in the ancient Greek world, Oxford.

Todd, S. C. (I994) 'Status and contract in fourth-century Athens', in G. Thür (ed.), Symposion 1993: Vorträge zur griechischen und hellenistischen Rechtsgeschichte, Bohlau, I25-40.

Toher, M. (I999) 'On the EI $\Delta \Omega \Lambda \mathrm{ON}$ of a Spartan king', Rheinisches Museum für Philologie I42.I, I8-26.

Trevett, J. (I992) Apollodoros, the son of Pasion, Oxford.

(2014) 'Review: Status in classical Athens', Bryn Mawr Classical Review 02.35.

Vlassopoulos, K. (2009) 'Slavery, freedom and citizenship in classical Athens: beyond a legalistic approach', European Review of History: Revue Européenne d'Histoire 16.3, 347-63.

Whitehead, D. (1977) The ideology of the Athenian metic, Cambridge.

Wijma, S. M. (2014), Embracing the immigrant: the participation of metics in Athenian polis religion (5th-4th century $B C)$, Stuttgart. 